\title{
Главный конструктор от Бога
}

Главному конструктору среднеоборотных двигателей ГП «Завод имени В.А. Мальиева», Заслуженному деятелю науки и техники Украинь, доктору технических наук, профессору, Зайончковскому Валентину Николаевичу посвящается. Валентин Николаевич был необычайно яркой, многосторонней, неординарной, творческой личностью. Поэтому редколлегия журнала и предлагает читателю неординарную структуру материала о нем, включающую воспоминания сподвижника по производственной и конструкторской деятельности, коллеги по педагогической работе в НТУ «Харьковский политехнический институт» и фрагмент его собственньх мемуаров.

\section{В.И. Стебленко,}

начальник КБ спец. дизель-электрических агрегатов в 1980-2005 г.г., выпускник ХПИ 1958г, лауреат премии Совета Министров в области науки и техники

Валентин Николаевич - потомственный «малышевец». Его отец Николай Викторович с 1915 по 1918 год работал молотобойцем в кузнечном цехе ХПЗ, потом учился, снова пришел на ХПЗ. Работал начальником табельно-нормировочного бюро завода, в 1937 году по ложным обвинениям был репрессирован и расстрелян как «враг народа».

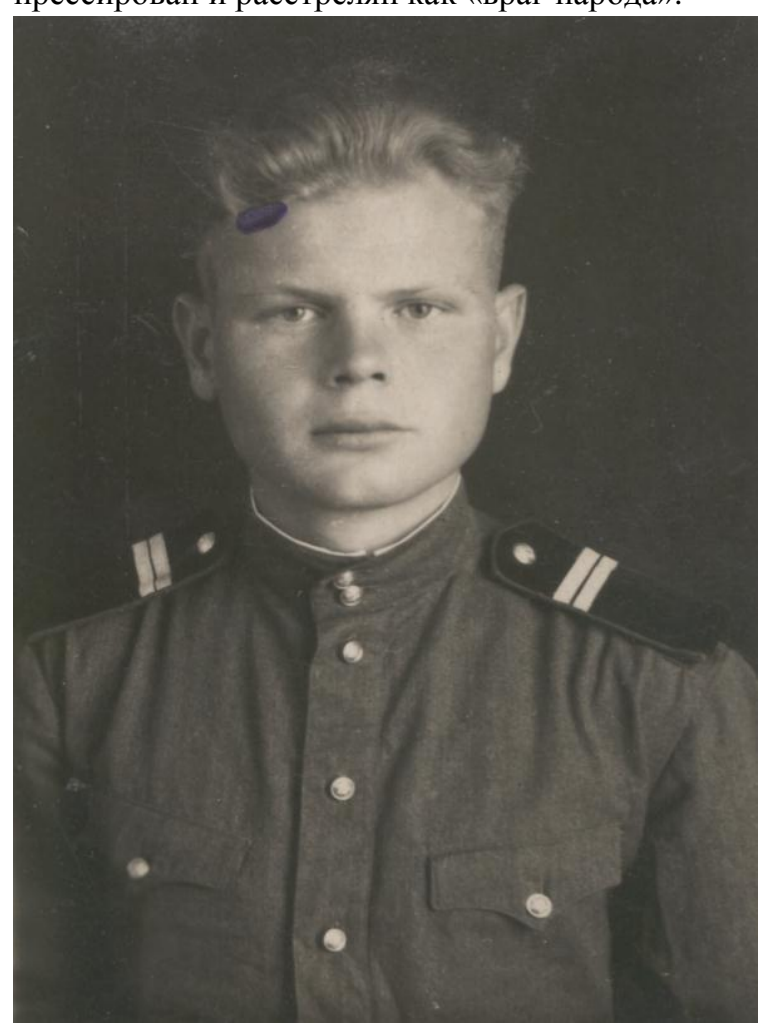

После семилетки Валентин пошел учиться в Харьковский механический техникум, выпускники которого в большинстве направлялись на ХПЗ. Затем срочная служба в танковых войсках и завершение учебы техникуме. В 1956 году Валентин Николаевич был распределен на завод им. В.А. Малышева, (бывший ХПЗ). Отдел кадров направил молодого специалиста в сектор агрегатов наддува дизельно-конструкторского отдела 60Д (в последующем отдел 66, КБСД). В конструкторском отделе он работал последовательно на всех должностях согласно штатному расписанию, предусмотренных для конструкторов.

Сразу же поступил на вечернее отделение ХПИ по специальности «Локомотивостроение», где в то же время под руководством заведующего кафедрой проф. С.М. Куценко перестраивалось обучение с паровозного на тепловозное направление с углубленным изучением ДВС.

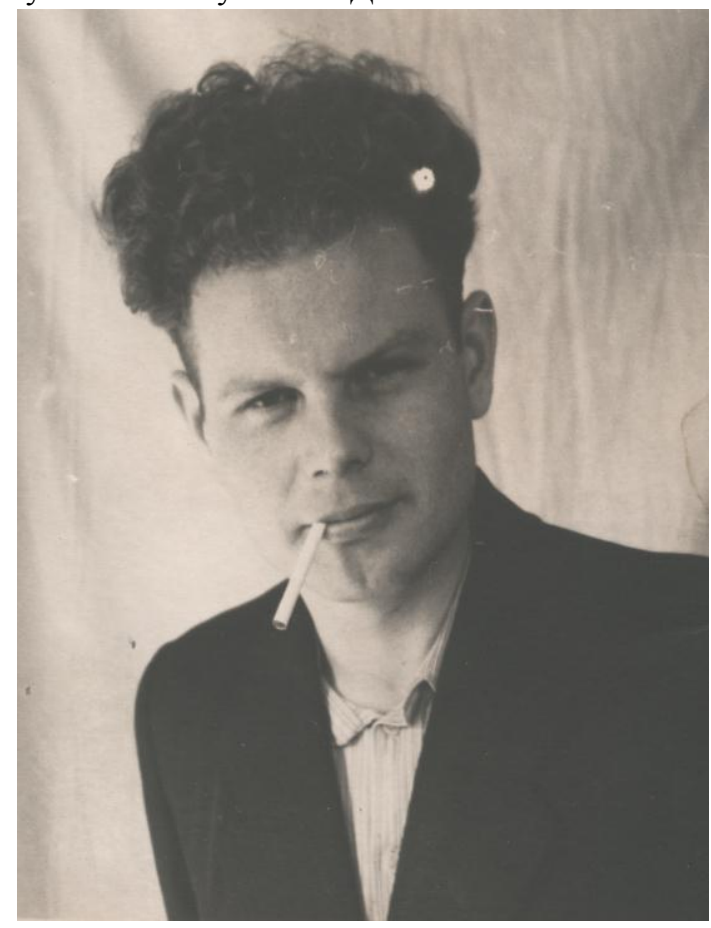

Первая самостоятельная работа начинающего конструктора - патрубок подвода газа к турбокомпрессору двигателя 9Д100 с разработкой кронштейна для установки турбокомпрессоров - была выполнена так, что не требовала подготовки производства. 
В 1956 - 1957 годах на заводе наращивалось серийное производство тепловозов новой конструкции ТЭ3 с дизель-генератором (ДГ) типа 2Д100 мощностью 1500 кВт. При этом в эксплуатации стали проявляться дефекты, которые не отмечались при стендовых и пробеговых испытаниях.

В частности, поступали сведения о поломке верхнего коленчатого вала как следствие заклинивания роторов приводной объемной воздуходувки типа Рут. Анализ разрушенных деталей показал, что вероятной причиной аварий может быть ослабление крепления синхронизирующих шестерен роторов. Для устранения поломок поступили предложения опытных конструкторов. Однако, после защиты предложений Главный конструктор Б.Н. Струнге принял к разработке вариант молодого специалиста, согласно которому гайка крепления шестерен стопорились винтами с плоской головкой (грибком и «левой» резьбой, которые вворачиваются в центральное отверстие в торце вала ротора и дополнительно фиксировались винтом малого диаметра).

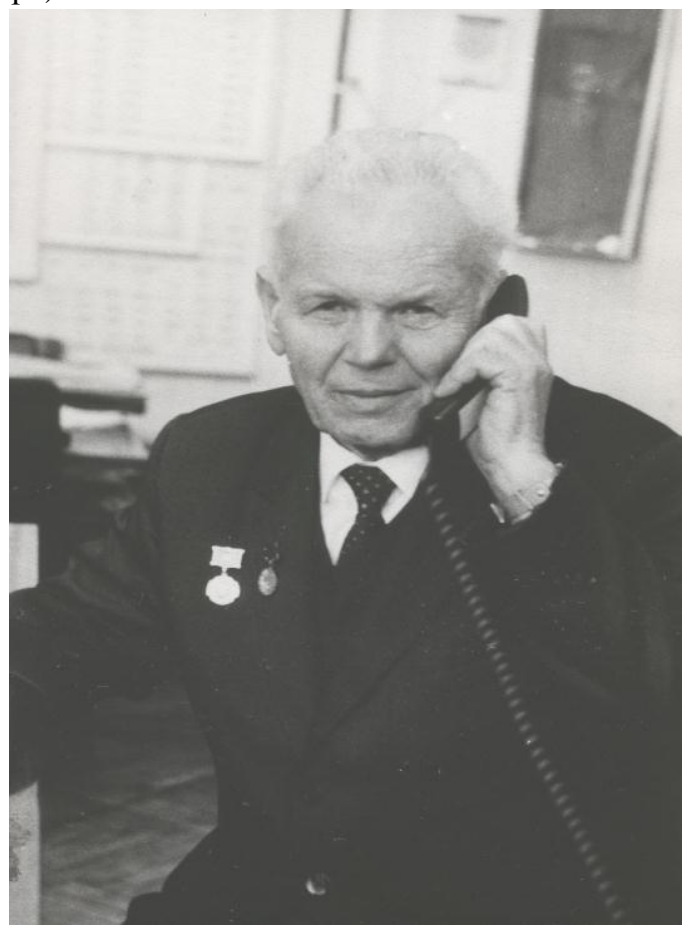

Данная конструкция стала результатом творческого подхода В.Н. Зайончковского к решению практической задачи с учетом технологичности и надежности. Дефект, приводивший к аварии, был устранен и в дальнейшем не проявлялся. Конструкторское решение признано рационализаторским (первое для автора).

Когда создавался специальный ДГ 15Д100М мощностью 1600 кВт при синхронной частоте вращения 750 мин $^{-1}$ на базе тепловозного ДГ $10 Д 100$ мощностью 2200 кВт при 850 мин $^{-1}$ с двухступенчатой системой наддува, экспериментально и расчетом было определено, что требования Т3 могут быть выполнены только заменой приводной центробежной воздуходувки нагнетателем объемного типа Рут, как у ДГ 2Д100, блок которого отличается от ДГ 10Д100. Поэтому на опытном образце ДГ 15Д100М воздухоохладители (ВО) были закреплены с двух сторон на блоке между турбокомпрессорами и Рут, что отразилось на снижении эффективности охлаждения наддувочного воздуха. В 1960-х г.г., будучи ведущим инженером по ДГ типа Д70 функционально руководителем разработок модификаций - Валентин Николаевич внес новаторское предложение по установке ВО после воздуходувки Рут ДТ 15Д100М, которое не нашло поддержки у опытных специалистов. Тогда автор на макете ДГ 2Д100 продемонстрировал возможность поместить (встроить) ВО в герметичные со стороны картера ниши, выполненные в блоке с двух сторон, используя свободное пространство картера. Скептицизм некоторых специалистов был опровергнут группой разработчиков-новаторов во главе с В.Н. Зайончковским. Были внесены существенные изменения в блок дизеля, разработаны ВО оригинальной конструкции, патрубки. Эта новаторская разработка была признана изобретением (первым для Зайончковского В.Н., Стебленко В.И., Велемчика С.А.) и реализована на ДГ 15Д100, который создавался 1969 - 1970 гг. В результате было достигнуто более глубокое охлаждение наддувочного воздуха, снижен удельный эффективный расход топлива на 4 $г /(\kappa В т \cdot ч)$.

В конце 60-х годов двигатель Д70, разрабатываемый на заводе, как внедрение результатов научных исследований кафедры ДВС ХПИ под руководством д.т.н. профессора Глаголева Н.Н., не имел по топливной экономичности себе равных. Зарубежные дизелестроительные фирмы достигли таких показателей где-то в конце 80-х годов.

Участвуя в проектировании, изготовлении и испытаниях двигателей Д70А и Д70Б, 2Д70, 6 Д70, 12 Д70, 3Д70, 5Д70, Валентин Николаевич решал задачи по ведущим узлам воздухоснабжения, передачам, выпускным системам.

Спроектированная им импульсная система наддува для двигателя $12 Д 70$ показала в эксплуатации лучший на 20\% среднеэксплуатационный расход топлива по сравнению с двигателем 2Д100, а в то время ученые ХИИТа подсчитали, что 5\% экономия топлива в эксплуатации окупает стоимость тепловоза за срок эксплуатации.

В 1974 году Валентин Николаевич был переведен в ХКБД и назначен начальником отдела но- 
вого проектирования. Была поставлена задача создания четырехтактного танкового двигателя, над которой Валентин Николаевич успешно работал.

В 1977 году В.Н. Зайончковский был назначен главным конструктором - начальником отдела 66 . Нужно отметить, что без опыта, полученного в ХКБД, вхождение в должность главного конструктора могло существенно затянуться, так как условия работы коллектива существенно отличались, в основном ответственностью за порученную работу, надо было привить эту черту в отделе 66. В ХКБД вместе с цехом в то время было 1300 работающих, а в 66 отделе всего 340 .

Валентин Николаевич в своей деятельности руководствовался базовым принципом, что главный конструктор это понятие коллективное, каждый должен чувствовать себя за чертежной доской главным конструктором, но принятие решений и ответственность за ГК. В сложившимся творческом коллективе, каким является конструкторский отдел или бюро, важна авторитетная иерархия, которая создается иногда годами. В конструкторском отделе продолжали работать три бывших главных конструктора Б.Н. Струнге, Н.П. Синенко и Л.Л. Голинец и новому Главному вскоре удалось наладить работу так, когда все конструкторские решения принимались как результат продуктивного консенcyca.

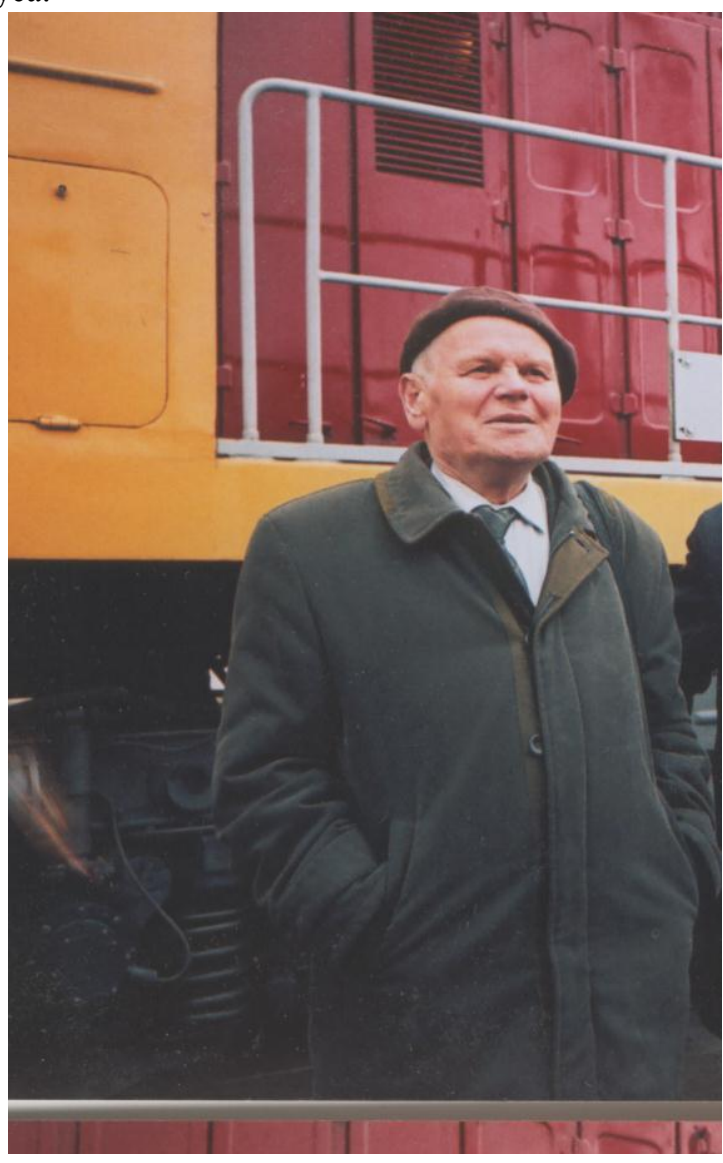

Основная работа коллектива конструкторов и исследователей была направлена на повышение технического уровня по показателям надежности и экономичности двигателя 10Д100. Для получения знака качества были разработаны мероприятия, конструктивные решения, проведены испытания и началось производство двигателей 10Д100M, 10Д100М1, 10Д100М2, 10Д100М1А.

В 1983 году по предложению МПС о возобновлении производства двигателей 2Д100, решением 3-х министров завод был освобожден от заданий по Д70 (105 спец. станков и вся изготовленная оснастка для серийного производства была списана). Но за заводом оставили тематику ОКР, обеспечение производства дизель-агрегатов 5Д70 - уникального двигателя для Министерства обороны. За его внедрение В.Н. Зайончковскому была присвоена государственная премия СССР.

На приведенных примерах разного времени и направлений работ показан инициативный, новаторский и целеустремленный подход Валентина Николаевича к решению конструкторских задач. Диапазон его таланта конструктора и творческих научно-технических интересов весьма широк.

Будучи Главным конструктором завода и Конструкторского бюро среднеоборотных двигателей администратором, видным ученым и действующим конструктором одновременно, д.т.н., проф. В.Н. Зайончковский держал под контролем всю многогранную творческую деятельность конструкторов и исследователей, не вмешиваясь, без необходимости, в ход работ. Ставил задачи, помогал выбирать направления их решения, вел проработки конструкций, определял размеры, объемы и формы деталей для выпуска рабочих чертежей. В его кабинете чертежная доска не простаивала без дела, каждый день на ней проступали черты новых узлов, размерных цепей, габаритов. Он считал важным соблюдение в творческом коллективе авторитетной иерархии специалистов по уровню компетенции, которая создается многими годами и достижениями. Он полностью доверял ведущим разработчикам по специализации. Вот некоторые: Галян В.Н.- по динамике и прочности, Веремчук С.А., Бобов Е.Ф.- по остову двигателей, Раскин В.Г., Заславский Е.Г.- по электрооборудованию и автоматизации, Тараканов С.Н,, Рузов В.А,- по регуляторам частоты вращения, Стебленко В.Н., Новикова T.А.- по спец. дизель-электрическим агрегатам, Гринберг Ф.Г., Эпштейн А.С.- по инженерным расчетам и ННР, Слюсарев Н.И., Черноморец В.Н.- по испытаниям и наладке ДГ и др. Доверие означало и большую ответственность за выполнение плановых заданий, инициативных разработок, за работы с 
заказчиками, проектантами объектов применения ДГ и в командировках на места применения, осуществляя авторский надзор.

Валентин Николаевич плодотворно совмещал работу на Заводе им. Малышева с научной и педагогической деятельностью.

Кандидатскую диссертацию В.Н. Зайончковский защитил в 1987 году, под давлением остепененных сотрудников, так как выполненный им анализ и выводы из проведенных исследований были полнее и конкретнее их предложений. При защите было отмечено, что объем представленных работ был бы достаточен на 3 - 4 диссертации, поэтому он продолжил научные исследования и в 1990 году подготовил докторскую диссертацию, которая была успешно защищена.

\section{В. Г. Маслієв}

професор кафедри електричного транспорту и тепловозобудування НТУ «ХПІ», доктор техн. наук, професор

Як завідувач кафедри на той час, я запросив Валентина Миколайовича прочитати курс лекцій студентам на кафедрі локомотивобудування стосовно сучасних проблем дизелебудування тому, що знав його як відомого фахівця із дизелебудування, доктора технічних наук, Головного конструктора 3 середньо-обертових двигунів внутрішнього згоряння, які призначені, перш за все, для тепловозів, та завзятого винахідника.

Ще у період навчання у ХПІ на кафедрі локомотивобудування Валентин Миколайович зарекомендував себе як відмінник навчання, творчий, веселий студент, а згодом на виробництві цілеспрямований конструктор.

Особливо важливо для мене було те, що всі, хто із ним спілкувався, вважали Валентина Миколайовича вельми цікавою, іскряною, доброю, внутрішньо обдарованою людиною, яка все, що мала, щедро віддає людям.

Це спонукало мене до того, щоб запропонувати Валентину Миколайовичу подовжити викладання курсу лекцій по теорії та практики створення економічних та надійних дизелів, та вивченню надскладних проблем сумісної роботи дизеля із різноманітними типами передач потужності тепловозів, що вкрай важливо для майбутніх фахівцівтепловозобудівників.

Як сумісник, Валентин Миколайович мав можливість читати лекції виключно по суботам, що викликало у мене певні сумніви щодо відвідування його лекцій нашими сучасними студентами, які зазвичай десь працюють, щоб заробити собі гроші на їжу і не тільки.
Але вже за кілька тижнів я побачив, що на його лекції приходять більшість студентів академічних груп. На питання до них, у чому секрет такого інтересу, вони дуже схвально відкликалися на методу викладання лекційного матеріалу, насиченість лекцій яскравими прикладами та щільним контактом Валентина Миколайовича із аудиторією. Це спонукало студентів до співпраці із ним та до ретельного вивчення матеріалу лекцій.

Нажаль, Валентина Миколайовича вже немає iз нами, але ми продовжуємо вчитися у нього гуманному відношенню до колег та студентів, вмінню аналізувати минулі та сучасні питання життя i досягнення технологій.

\section{В.Н. Зайончковский \\ фрагмент из мемуаров}

«Всякая бюрократия являет собой замаскированный бардак. И в работе немецкой оккупационной военно-административной машины беспорядка было не меньше, чем где бы то ни было.

Впервые мы столкнулись с этим, когда моя мама Анна Ивановна Тарасевич решила поехать в Полтавскую область на менку. Наиболее удобно было ехать по железной дороге, но предварительно надо было получить разрешение на проезд. В 11 часов утра мы пришли на привокзальную площадь, заняли очередь. Очередь - человек сто, запускали в здание управления Южной железной дороги по десять просителей. К хвосту подошел представительный мужчина с портфелем и предложил: «Я могу помочь получить аусвайсы в течение получаса для десяти человек, для этого сдавайте по 10 марок. С кем-нибудь из вас мы пойдем в кафе, купим пирожных для переводчиц на завтрак и я вынесу разрешения». Мама сразу согласилась, отдала документы и деньги, а когда набралось десять желающих, один из потенциальных пассажиров пошел с посредником, и вскоре принес взяткодателям необходимые проездные аусвайсы. Любую дверь всегда можно было открыть бумажным ключом.

Примеров подобного «немецкого порядка» множество, но наиболее яркий случай произошел с Борисом Михайловичем Соколовым, потомственным пролетарием и нашим соседом. Во время второй оккупации Харькова (15 марта - 23 августа 1943 г.) в самом начале улицы Плехановской некий Яшка-армянин открыл магазин-кафе, был там прилавок и несколько столиков. Мы, пацаны, любили туда приходить посмотреть (денег естественно не было) на разные диковины - пирожные, колбаса, хлеб. Однажды заходим, сидит за столом Борис Михайлович, курит, перед ним - стакан шнапса, 
напротив - немецкий фельд-жандарм с дугообразной бляхой на цепи. Жандарм передвинул стакан и поставил возле себя, а Борис Михайлович докурил, взял стакан и выпил. Немец начал на него кричать, Борис Михайлович - ему в морду, мы испугались и дали из магазина ходу. Через несколько минут Яшка-армянин и фельд-жандарм вывели Бориса Михайловича на улицу, немец остановил машину, и залез с нашим соседом в кузов.

Только после войны, когда мы с приятелем вечером чистили в мастерской велосипедные детали от ржавчины (Борис Михайлович их никелировал, собирал велосипед, продавал, а нам давал на кино и мороженое), мы узнали, чем кончилась эта история. Машина остановилась у здания городского гестапо на улице Совнаркомовской (до войны там было НКВД, после войны - МГБ, КГБ и СБУ). Немец завел Соколова в вестибюль, а там, у внутренней двери стоял автоматчик, жандарм приказал что-то часовому и вышел, а тут пришла смена караула, старый часовой, ничего не сказав, ушел, а наш сосед сделал вид, что хочет зайти внутрь здания. Новый страж, вполне естественно, стал кричать и преградил автоматом путь. «Я, говорит Борис Михайлович, махнул рукой, вышел, и пошел себе спокойно домой». Так на одну жертву немецких фашистов в Харькове стало меньше». 


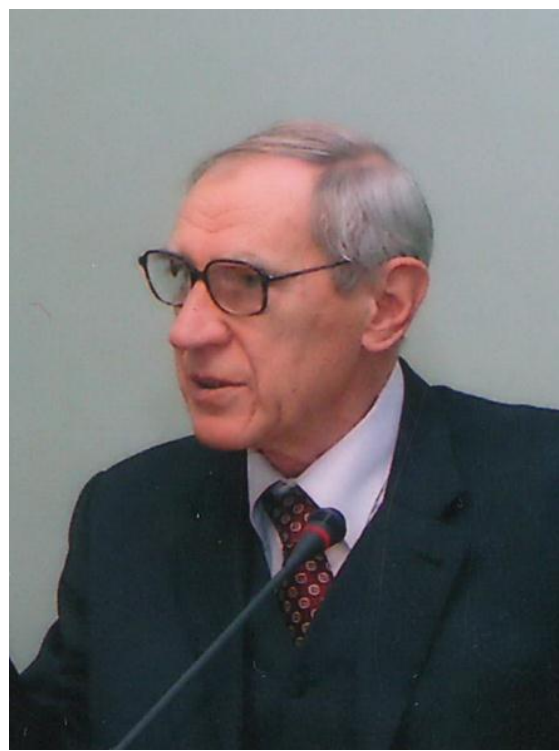

Выдающемуся ученому, специалисту в области рабочих
процесов и автоматического регулирования дизелей

\section{СТАНИСЛАВУ АРКАДЬЕВИЧУ ЕРОЩЕНКОВУ -} 80 ЛЕТ!

С.А. Ерощенков родился 23 июля 1936 года. В 1959 году окончил Харьковский политехнический институт по специальности «Двигатели внутреннего сгорания». Работал инженером-исследователем на Ярославском моторном заводе, в конструкторском бюро ОГК по двигателестроению ПО «Завод им. В.А. Малышева».

С 1964 года аспирант, старший инженер, старший научный сотрудник кафедры «Теплотехника» Харьковского института железнодорожного транспорта. В 1968 году защитил кандидатскую диссертацию, в 1989 г. - докторскую диссертацию на тему «Улучшение топливной экономичности и эксплуатационных характеристик транспортных двигателей путем выбора рациональных конструктивных параметров и совершенствования систем регулирования». С 1991 более 20 лет возглавлял кафедру «Теплотехника и тепловые двигатели», успешно совмещая административную, преподавательскую и научную деятельность. Основная тематика научных работ связана с повышением технико-экономических показателей, эксплуатационной экономичности и решение экологических проблем эксплуатации железнодорожного транспорта. Все эти годы был членом специализированного ученого совета и редколлегии нашего журнала. С. А. Ерощенков подготовил 2-х докторов и шесть кандидатов технических наук, автор около 150 научных публикаций.

Уважаемый Станислав Аркадьевич, примите наши искренние поздравления с юбилеем, пожелания успехов, счастья, здоровья. Мы Вас ценим, уважаем и любим.

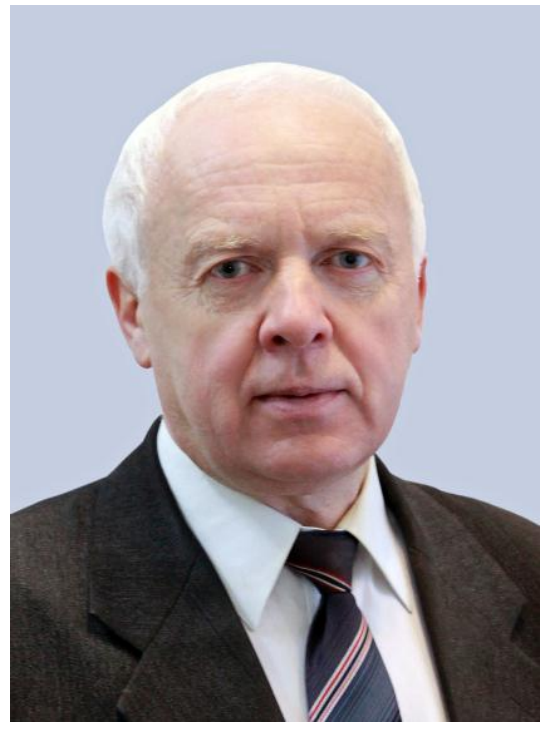

\section{АЛЕКСАНДРУ ВАСИЛЬЕВИЧУ ГРИЦЮКУ 60ЛЕТ!}

1 апреля 2016 года исполнилось 60 лет Александру Васильевичу Грицюку заместителю генерального конструктора по научно-исследовательской работе - главному конструктору ГП "ХКБД", доктору технических наук

А.В. Грицюк родился в городе Лозовая Харьковской области. В 1979 году закончил с отличием Харьковский политехнический институт по специальности "Двигатели внутреннего сгорания" и был направлен в ХКБД при заводи им. В.О. Малышева, где и работает по настоящее время. Прошел путь от инженера-исследователя до главного конструктора.

С 1985 года по 1989 год без отрыва от производства закончил аспирантуру при МВТУ им. Н.Э. Баумана. Занимался очень актуальной и важной задачей холодного пуска танкового двигателя, и в 1990 году успешно защитил кандидатскую диссертацию.

С 2004 года - заместитель генерального конструктора по научноисследовательской работе - главный конструктор Государственного предприятия "Харьковское конструкторское бюро по двигателестроению". Внес большой вклад в сохранение и развитие научно-исследовательской базы конструкторского бюро.

А.В. Грицюк является одним из инициаторов, научным руководителем и ответственным исполнителем Государственной программы развития производства отечественных малолитражных дизельных двигателей и силовых и энергетических установок для агропромышленного комплекса в 2006 - 2010 годах и инвестиционного проекта «Создание производства отечественного малолитражного автомобильного дизеля мощностью 100 - 175 л.с. двойного назначения (Слобожанский дизель)». В 2010 года защитил докторскую диссертацию «Теоретические основы и практические методы создания высокооборотного малолитражного дизеля многоцелевого назначения». С сентября 2010 года совмещает основную производственную деятельность с преподавательской, является доцентом кафедры ДВС ХНАДУ.

Александр Васильевич член двух специализированных ученых советов по специальности двигатели и энергетические установки - в НТУ "ХПИ" и ХНАДУ. Входит в состав редколлегии нашего журнала. Является автором свыше 75 научных работ. Под его руководством защищена 1 кандидатская диссертация.

Александр Васильевич! Сердечно поздравляем Вас с юбилеем, желаем ему крепкого здоровья, новых достижений и творческих успехов. 